\title{
Pengaruh Pencapaian Biologi dan Kimia Peringkat SPM dalam Meramal Pencapaian Pelajar bagi Subjek Biologi Manusia
}

\author{
Hishamuddin Ahmad*, Siti Eshah Mokshein
}

Fakulti Pembangunan Manusia, Universiti Pendidikan Sultan Idris, 35900 Tanjong Malim, Perak

*Corresponding author: hishamuddin.a@fpm.upsi.edu.my

\begin{abstract}
The purpose of this study is to identify differences in the results of the semester examinations for the Human Biology subject of the Diploma in Medical Laboratory Technology (DMLT) program for science and non-science stream students at the Sijil Pelajaran Malaysia (SPM) level as well as the achievement of male and female students. Furthermore, this study is also intended to predict the results of the Human Biology subject based on the SPM subjects of Biology and Chemistry. This study is a quantitative study involving the analysis of students' Human Biology subjects for the July-December 2012 session using multiple regression analysis with SPM results as independent variables. The sample used was 40 students who were randomly selected from the College of Medical Laboratory Technology, Kuala Lumpur, and the Allied Health Science College, Kuching, Sarawak. The results of the data analysis showed that the achievement of students from the science stream in the Human Biology subject was better $(\mathrm{p}<0.05 ; \mathrm{t}=-3.653$; $\mathrm{df}=38)$ than students from non-science streams and the difference in achievement was significant at $95 \%$ confidence level. At the same time, the achievement of female students showed better results $(\mathrm{p}<0.05 ; \mathrm{t}=-2.082 ; \mathrm{df}=38)$ as compared to male students. Pearson correlation analysis showed a very strong positive correlation for Biology $(r=0.632(39), p<0.05)$ and Chemistry $(r=0.678(39), p<0.05)$ subjects grades to Human Biology subject scores. Linear multiple regression analysis showed that the combined grades of Biology and Chemistry subjects at the SPM level predicted $49.1 \%$ of the Human Biology subject scores variant at DMLT level. The implication of this study suggests that candidates from the science stream with better grade results especially in Biology and Chemistry subjects at the SPM level should be given priority for the enrolment to the DMLT program. Since the DMLT program cannot be exclusively offered to female candidates even though the female group is able to achieve better results, male candidates' enrolment need to be continued. However, more attention should be given to the male students especially during the learning session of Human Biology subject.
\end{abstract}

Keywords: Students' achievement predictor; human biology; biology; chemistry

Abstrak

Tujuan kajian ini adalah untuk mengenal pasti perbezaan keputusan peperiksaan akhir semester bagi subjek Biologi Manusia program Diploma Teknologi Makmal Perubatan (DTMP) bagi pelajar lepasan aliran sains dan bukan-sains di peringkat Sijil Pelajaran Malaysia (SPM) serta pencapaian antara pelajar lelaki dan perempuan. Seterusnya, kajian ini juga bertujuan meramal keputusan subjek Biologi Manusia berdasarkan keputusan SPM subjek Biologi dan Kimia. Kajian ini merupakan kajian kuantitatif yang melibatkan analisis keputusan subjek Biologi Manusia pelajar bagi sesi pengajian Julai-Disember 2012 menggunakan analisis regresi berganda dengan keputusan SPM sebagai pemboleh ubah bebas. Sampel kajian adalah seramai 40 orang pelajar yang dipilih secara rawak berstrata dari Kolej Teknologi Makmal Perubatan, Kuala Lumpur dan Kolej Sains Kesihatan Bersekutu, Kuching, Sarawak. Keputusan analisis data menunjukkan bahawa pencapaian pelajar yang berasal dari aliran sains dalam subjek Biologi Manusia adalah lebih baik $(p<0.05 ; t=-3.653 ; d f=38)$ berbanding pelajar dari aliran bukan-sains dan perbezaan pencapaian ini adalah signifikan pada aras keyakinan $95 \%$. Pada masa yang sama, pencapaian pelajar perempuan menunjukkan keputusan yang lebih baik dalam subjek Biologi Manusia $(p<0.05 ; t=-2.082 ; d f=38)$ berbanding pelajar lelaki. Analisis korelasi Pearson menunjukkan korelasi positif yang sangat kuat bagi gred subjek Biologi $(r=0.632(39), p<0.05)$ dan subjek Kimia $(r=0.678(39), p<0.05)$ terhadap markah subjek Biologi Manusia. Analisis regresi berganda linear menunjukkan bahawa gabungan gred subjek Biologi dan Kimia di peringkat SPM dapat meramal sebanyak 49.1\% daripada varian markah subjek Biologi Manusia di peringkat DTMP. Implikasi daripada kajian ini mencadangkan agar calon dari aliran sains dengan keputusan gred yang lebih baik khususnya bagi subjek Biologi dan Kimia di peringkat SPM diberikan keutamaan sebagai syarat pemilihan untuk mengikuti pengajian program DTMP. Oleh kerana pengajian program DTMP tidak boleh dieksklusifkan kepada calon perempuan sahaja walaupun golongan ini mampu memperoleh pencapaian yang lebih baik, pengambilan calon lelaki perlu diteruskan. Walau bagaimanapun, perhatian yang lebih perlu diberikan kepada pelajar lelaki khususnya dalam pembelajaran subjek Biologi Manusia. .

Kata Kunci: Peramal pencapaian pelajar, biologi manusia, biologi, kimia

(C) 2017 Penerbit UTM Press. All rights reserved

\subsection{PENGENALAN}

Di dalam Kementerian Kesihatan Malaysia (KKM), terdapat dua buah institusi yang menawarkan program Diploma Teknologi Makmal Perubatan (DTMP) iaitu Kolej Teknologi Makmal Perubatan (KTMP), Kuala Lumpur dan Kolej Sains Kesihatan Bersekutu (KSKB), Kuching, Sarawak. Pelajar yang mengikuti program DTMP di KKM adalah calon-calon yang telah terpilih oleh pihak Suruhanjaya Perkhidmatan Awam (SPA) berdasarkan syarat-syarat kemasukan yang telah ditetapkan. Secara amnya, syarat tersebut menyasarkan calon-calon yang berumur dalam lingkungan umur 17 hingga 25 tahun yang memperoleh keputusan SPM yang baik dari aliran sains atau 
bukan sains. Selain daripada keperluan memenuhi syarat-syarat yang telah dinyatakan, calon juga perlu berjaya dalam sesi temu duga yang diuruskan oleh pihak SPA serta lulus Ujian Aptitud (menaksir minat dan sahsiah diri) yang diduduki sejurus sebelum sesi temu duga berlangsung. Ini bermaksud, calon-calon yang dipilih telah mempunyai kelayakan minimum yang diperlukan bagi mengikuti pengajian dalam program DTMP serta boleh juga dianggap sebagai mempunyai minat, sahsiah diri, keterampilan yang diperlukan dan mempunyai potensi untuk berjaya dalam program yang diikuti.

Calon yang memenuhi syarat-syarat kelayakan serta lulus ujian aptitud dan temu duga akan memulakan pengajian program DTMP sama ada di KTMP, Kuala Lumpur atau KSKB, Kuching dengan dibiayai sepenuh pengajiannya oleh pihak KKM dengan pelbagai elaun yang diterima pada setiap bulan termasuk dengan pelbagai fasiliti tambahan selama dalam tempoh pengajian (Bahagian Pengurusan Latihan, 2010). Breier (2010) dalam kajian beliau di Afrika mendapati bahawa punca kegagalan ramai pelajar dalam pembelajaran adalah kerana mereka sangat miskin. Namun, kegagalan yang disebabkan oleh faktor kemiskinan tidak sepatutnya berlaku ke atas pelajar-pelajar DTMP di Malaysia kerana pengajian mereka adalah ditanggung sepenuhnya oleh pihak KKM.

Semasa mengikuti pengajian di Tahun 1 Semester I, pelajar akan mempelajari subjek Biologi Manusia, Imunologi, Biokimia, Kimia, Instrumentasi, dan Statistik yang berjumlah 17 mata kredit (Bahagian Pengurusan Latihan, 2012). Subjek Biologi Manusia merangkumi topik Fungsi dan Struktur Sel, Pembahagian Sel, Teori Perwarisan, Kromosom Manusia, Biologi Molekul Asas, Konsep Asas PCR, Rekombinan DNA, Tisu dan Organ, Sistem Respiratori, Sistem Alimentari, Sistem Ekskretori, Sistem Peredaran Darah, Sistem Limfatik, Sistem Reproduktif, Sistem Endokrin, dan Sistem Saraf (Kementerian Kesihatan Malaysia, 2007). Kebanyakan topik tersebut adalah sebenarnya terdiri daripada komponen bidang Anatomi dan Fisiologi. Khurana, Khurana, Hwee Ming, Selvaratnam, Wan Ling, dan Soo Nyet (2010), menyatakan bahawa 'anatomi' terbahagi kepada lima bidang iaitu grosss anatomy, surface anatomy, embryology, histology, dan radiographic anatomy. Subjek Biologi Manusia merangkumi semua bidang tersebut kecuali radiographic anatomy. 'Fisiologi' pula menurut Khurana et al. (2010) lagi, adalah merujuk kepada kajian terhadap fungsi struktur tubuh manusia. Ia berkaitan dengan pelbagai sistem dalam fungsi tubuh manusia dan sumbangan setiap nya kepada fungsi tubuh secara keseluruhan.

Di sepanjang pengajian, pelajar akan dinilai dengan ujian berterusan di dalam bilik kuliah, peperiksaan pertengahan semester dan peperiksaan akhir semester dalam bentuk item aneka pilihan, esei pendek dan amali. Walau bagaimanapun, ujian bagi subjek Biologi Manusia adalah dalam bentuk item aneka pilihan dan esei pendek sahaja. Wright dan Linacre (1994) menyatakan bahawa item aneka pilihan dianggap sebagai bentuk penilaian objektif dengan kebolehpercayaan yang tinggi. Tetapi peluang untuk pelajar menunjukkan pengetahuan dan kefahaman yang dimiliki adalah terhad oleh kerana keobjektifan nya. Maka, bagi melengkapkan kelemahan tersebut, soalan berbentuk esei pendek turut disediakan untuk memberi peluang kepada pelajar menjelaskan jawapan mereka, sekali gus berpotensi meningkatkan kedalaman dan skop maklumat yang dapat dikumpul daripada pelajar (Wright \& Linacre, 1994).

Rasional bagi menjalankan kajian ini adalah bagi menyediakan bukti empirikal kepada pihak yang bertanggungjawab dalam pengambilan pelajar, pihak kolej dan tenaga pengajar agar pelajar yang benar-benar layak sahaja dipilih untuk mengikuti pengajian DTMP. Oleh kerana ketiadaan kajian yang seumpama ini dijalankan sebelum ini terhadap pelajar-pelajar DTMP di KKM, maka hasil kajian akan menjadi maklumat yang berguna dalam membuat keputusan berkaitan pengambilan pelajar.

Daripada maklum balas secara verbal yang kerap diterima daripada tenaga pengajar, pelajar-pelajar yang berasal dari aliran bukan-sains semasa di peringkat sekolah menengah didapati kurang berupaya untuk menguasai subjek-subjek yang ditawarkan semasa mengikuti pengajian dalam program DTMP. Data ambilan pelajar bagi sesi Julai-Disember 2012 menunjukkan bahawa 11 orang pelajar di KTMP, Kuala Lumpur dan kesemua 25 orang pelajar di KSKB, Kuching adalah dari aliran sains manakala yang selebihnya seramai 9 orang pelajar adalah dari aliran bukan-sains.

\section{Pernyataan Masalah}

Dalam pembentangan keputusan peperiksaan akhir semester sesi Julai-Disember 2012 bagi Tahun 1 Semester I program DTMP, analisis keputusan peperiksaan akhir semester menunjukkan tahap kelulusan subjek Biologi Manusia di KTMP, Kuala Lumpur didapati sangat rendah dengan kadar kelulusan hanya 50 peratus sahaja berbanding kadar 96 peratus bagi KSKB, Kuching. Keadaan tersebut telah menggambarkan seolah-olah terdapat satu golongan pelajar yang kurang berupaya atau sangat lemah untuk menguasai pembelajaran pada peringkat awal pengajian dari tempoh keseluruhan selama tiga tahun program DTMP khususnya terhadap subjek Biologi Manusia.

Daripada jumlah keseluruhan 45 orang pelajar di kedua-dua kolej tersebut, 11 orang pelajar telah gagal dalam subjek Biologi Manusia. Di Institut Latihan Kementerian Kesihatan Malaysia (ILKKM), pelajar perlu mendapat markah sekurang-kurangnya 50 peratus untuk lulus (Kementerian Kesihatan Malaysia, 2009). Kadar kegagalan yang tinggi tersebut mungkin ada kaitan dengan faktor pencapaian pelajar semasa di peringkat SPM. Jika kadar kelulusan yang tidak memuaskan tersebut berterusan atau berlarutan, berkemungkinan ia akan menjejaskan imej institusi latihan di Kementerian Kesihatan Malaysia, kolej dan tenaga pengajar secara keseluruhannya.

Walaupun pelajar-pelajar yang dipilih telah memenuhi semua syarat kemasukan, tetapi syarat-syarat tersebut tidak menyatakan dengan khusus bahawa calon perlu mempunyai kelayakan minimum yang baik bagi mata pelajaran sains tulen (Biologi dan Kimia). Syarat minimum keutamaan pemilihan hanyalah dinyatakan sebagai 'lulus dengan kredit dalam mata pelajaran Sains dan Matematik serta tiga mata pelajaran lain' (Bahagian Pengurusan Latihan, 2014). Hecker dan Violato (2008) dalam kajian mereka mendapati bahawa pengetahuan asas terdahulu tentang sesuatu bidang pengajian yang akan diikuti adalah amat penting. Syarat kemasukan khususnya pencapaian di peringkat SPM sangat perlu diambil perhatian terutamanya bagi subjek-subjek SPM seperti Biologi dan Kimia yang berkaitan dengan subjek Biologi Manusia. Maka, bagi mengukur pengaruh pencapaian Biologi dan Kimia peringkat SPM dalam meramal pencapaian pelajar bagi subjek Biologi Manusia tersebut, satu kajian perlu dilakukan.

\section{Objektif Kajian}

Tujuan kajian ini dijalankan adalah untuk mengenal pasti perbezaan antara pelajar dari aliran sains dan bukan-sains di peringkat SPM dalam pencapaian keputusan peperiksaan akhir semester bagi subjek Biologi Manusia program DTMP. Tambahan kepada itu, perbezaan dalam pencapaian keputusan subjek Biologi Manusia program DTMP antara pelajar lelaki dan perempuan juga turut dikenal pasti. 
Oleh kerana kajian-kajian lepas mendapati bahawa skor ujian dan pencapaian sekolah menengah adalah peramal terbaik untuk kejayaan di kolej (Neill, 2011; Hecker \& Violato, 2008; Noftle \& Robins, 2007; Mathiasen, 1984), maka kajian ini juga menentukan sejauh mana keputusan subjek Biologi dan Kimia di peringkat SPM dapat meramal pencapaian pelajar dalam subjek Biologi Manusia.

\section{Soalan Kajian}

1. Adakah terdapat perbezaan yang signifikan dalam keputusan subjek Biologi Manusia program DTMP antara pelajar dari aliran sains dan bukan-sains di peringkat SPM?

2. Adakah terdapat perbezaan yang signifikan di antara pelajar lelaki dan perempuan dalam keputusan subjek Biologi Manusia program DTMP?

3. Sejauh manakah keputusan subjek Biologi dan Kimia di peringkat SPM dapat meramal pencapaian pelajar dalam subjek Biologi Manusia program DTMP?

\subsection{TINJAUAN LITERATUR}

Kerangka konseptual kajian adalah berdasarkan teori-teori yang diperoleh daripada kajian lepas. Neill (2011) dan Mathiasen (1984) daripada kajian mereka mendapati bahawa skor ujian dan pencapaian terdahulu di sekolah menengah adalah peramal terbaik untuk kejayaan di kolej. Pencapaian di kolej tentunya juga berkaitan dengan aliran ketika pelajar berada di peringkat sekolah menengah kerana subjek-subjek yang dipelajari adalah bergantung kepada aliran yang diikuti. Menurut Zalizan, Saemah, Roselan, dan Jamil (2005), aliran di peringkat sekolah menengah dibahagikan kepada empat iaitu sains, sastera, agama, dan teknik. Aliran sains menawarkan kombinasi subjek-subjek sains tulen iaitu Biologi, Kimia, Fizik, dan Matematik Tambahan selain daripada subjek-subjek standard yang lain. Manakala kombinasi subjek yang ditawarkan bagi aliran bukan-sains adalah yang selain daripada yang telah dinyatakan. Kajian ini mengkategorikan aliran sastera, agama, dan teknik sebagai bukan-sains.

Hasil kajian yang telah dijalankan oleh Lestari (2010) mendapati bahawa keputusan akademik pelajar perempuan adalah lebih baik daripada pelajar lelaki. Dapatan yang sama turut diperoleh oleh Zalizan et al. (2005). Walau bagaimanapun, kajian yang telah dijalankan oleh Patrick (2012) ke atas 637 orang pelajar terhadap keputusan subjek Biologi, Kimia, dan Fizik mendapati gred yang diperoleh dalam subjek Kimia dan Fizik oleh pelajar lelaki lebih baik berbanding pelajar perempuan, manakala tidak terdapat perbezaan yang signifikan antara lelaki dan perempuan dalam keputusan subjek Biologi.

Campbell, Mitchell, dan Reece (1994) mendefinisikan terma 'Biologi' sebagai kajian saintifik tentang kehidupan atau juga dikenali sebagai Sains Hayat. Di peringkat sekolah menengah, pembelajaran subjek Biologi memberi tumpuan kepada pengetahuan saintifik yang diperlukan dalam bidang kajian saintifik tentang kehidupan yang berorientasikan kegiatan amali dan kajian lapangan (Kementerian Pendidikan Malaysia, 1998). Manakala bagi pembelajaran subjek Kimia di sekolah menengah pula, komponennya adalah terdiri daripada kajian tentang jirim secara makroskopi dan mikroskopik, interaksi antara bahan dan penghasilan serta penggunaan bahan (Pusat Perkembangan Kurikulum, 2000).

Holstein, Schulze, dan Davidoff (2003) daripada kajian mereka mendapati bahawa di sepanjang pembelajaran tentang proses spermatogenesis yang kompleks, pelajar memerlukan maklumat asas yang terperinci tentang organisasi germinal epithelium, struktur dan fungsi sel-sel germa yang berbeza, endokrin, sel-sel paracrine, mekanisme, intratesticular, dan extratesticular spermatogenesis. Holstein et al. (2003) menegaskan bahawa pengetahuan mendalam tentang proses spermatogenesis yang rumit dan semua sel atau sistem sel yang terlibat adalah prasyarat untuk membangunkan konsepnya. Ini bermaksud, pengetahuan asas tentang sesuatu subjek yang akan dipelajari adalah amat penting agar pelajar dapat membina kefahaman yang baik.

Majoriti variasi antara kolej-kolej berkaitan peperiksaan boleh diambil kira dalam perbezaan kemasukan pelajar, kebanyakannya melalui skor ujian kemasukan kolej (Hecker \& Violato, 2008; Noftle \& Robins, 2007). Hecker dan Violato (2008) menambah lagi bahawa perbezaan pelajar-pelajar tersebut menyumbang kepada lebih daripada $85 \%$ daripada jumlah variasi dalam kolej. Ini bermaksud, penilaian prestasi pelajar sebelum masuk ke kolej adalah sangat penting bagi meramal pencapaian akademik mereka. Noftle dan Robins (2007) seterusnya dalam kajian mereka mendapati bahawa, walaupun skor ujian kemasukan kolej dan pencapaian sekolah menengah adalah dua maklumat yang paling mujarab sebagai peramal kepada gred di kolej, tetapi mereka berpendapat bahawa gred sekolah menengah biasanya memainkan peranan yang lebih besar.

Sebuah kolej di Amerika Syarikat, telah menetapkan bahawa pelajar yang ingin mengambil kursus Biologi perlu lulus dengan mendapat markah sekurang-kurangnya 70 peratus bagi subjek Foundations of Life Sciences. Foundations of Life Sciences adalah subjek yang terdiri daripada komponen subjek Biologi and Kimia. Pihak kolej tersebut berpendapat, dengan mengenakan syarat sebegitu, peluang kejayaan pelajar terhadap subjek berkaitan anatomi dan fisiologi akan meningkat (Tidewater Community College, 2013). Jadi, pengetahuan asas dalam bidang Biologi dan Kimia merupakan faktor yang perlu diambil kira sebagai asas pembelajaran dalam bidang anatomi dan fisiologi.

Scanlon dan Sanders (2011) pula menyatakan bahawa anatomi tubuh manusia sendiri adalah sebenarnya sebuah struktur jitu yang bertindak sebagai takungan pelbagai bahan kimia dan reaksi kimia. Kenyataan mereka telah menguatkan lagi bahawa subjek kimia adalah berkaitan dengan pembelajaran subjek Biologi Manusia. Bagi menjelaskan konsep berkaitan fisiologi, Scanlon dan Sanders (2011) dalam buku mereka sendiri telah memulakannya dengan aras yang paling mudah iaitu berkaitan dengan topik kimia organik dan kimia bukan organik. Ini bermaksud, di samping pengetahuan tentang bidang biologi, peranan pengetahuan asas tentang ilmu kimia adalah penting dalam pembelajaran subjek Biologi Manusia.

Tambahan pula, hampir semua subjek yang ditawarkan dalam pengajian DTMP adalah amat berkaitan dengan bidang sains. Jonid dan Ahmad Razali (2010) pula mendapati bahawa subjek berkaitan Biologi adalah abstrak. Menurut mereka, grafik, audio, video, dan animasi yang realistik dan menarik akan mempermudahkan pelajar memahami konsep yang abstrak dalam subjek Biologi. Dalam program DTMP, pembelajaran Biologi Manusia didapati menggunakan banyak kaedah grafik, audio, video, dan animasi yang realistik bagi memudahkan pemahaman terhadap sesuatu abstrak.

Kesimpulan daripada kajian-kajian lepas menunjukkan bahawa pengetahuan yang diperoleh daripada peringkat sekolah menengah adalah penting sebagai asas dalam pengajian di peringat yang lebih tinggi. 


\subsection{METODOLOGI KAJIAN}

\section{Reka Bentuk Kajian}

Kajian ini merupakan kajian kuantitatif dengan reka bentuk deskriptif dan inferensi yang melibatkan penyiasatan tentang faktor-faktor peramal kepada pencapaian pelajar dalam subjek Biologi Manusia. Menurut Manoharan (2009), reka bentuk kajian deskriptif adalah berkaitan dengan situasi, perhubungan atau pola yang wujud di antara pemboleh ubah-pemboleh ubah tanpa mengubah alam sekitar. Warner (2008) pula mendapati, apabila hasil keputusan statistik atau skor bagi sampel kajian digunakan untuk membuat inferens terhadap populasi, ia dikenali sebagai statistik inferens. Tujuan analisis statistik inferens dijalankan adalah bagi membuat kesimpulan (inferens) tentang keadaan yang berlaku di dalam populasi daripada sampel yang diperoleh secara rawak daripada sesuatu populasi (King \& Minium, 2008).

\section{Prosedur Kajian}

Peringkat pertama kajian telah dijalankan pada bulan Januari 2013 dengan menyemak data-data keputusan dan analisis peperiksaan akhir semester sesi Julai-Disember 2012 program DTMP setelah mendapat kebenaran daripada pihak Unit Peperiksaan dan Pensijilan, Bahagian Pengurusan Latihan, KKM. Setelah mendapat kebenaran daripada Pengarah KTMP, Kuala Lumpur dan Pengarah KSKB, Kuching melalui surat dengan rujukan (93) KKM-510-5/7 Jilid. 19 bertarikh 23 November 2012, peringkat kedua kajian pula dijalankan dengan mengemukakan borang pemungutan data dengan senarai sampel kajian (nama dan nombor matriks) bagi mendapatkan maklumat berkaitan jantina, aliran, gred subjek Biologi, dan gred subjek Kimia di peringkat SPM kepada Pengarah di kedua-dua kolej tersebut.

Analisis awal terhadap item-item aneka pilihan dan esei pendek subjek Biologi Manusia bagi Peperiksaan Akhir Semester Tahun 1 Semester I sesi Julai-Disember 2012 mendapati item-item yang digunakan telah memenuhi kehendak kurikulum dan garis panduan penyediaan item. Proses penggubalan item didapati telah merujuk kepada kurikulum, objektif pembelajaran, dan jadual spesifikasi ujian yang telah ditetapkan.

\section{Pensampelan Kajian}

Bagi sesi pengajian Julai-Disember 2012, terdapat seramai 45 orang pelajar lelaki dan perempuan yang telah menduduki subjek Biologi Manusia dalam peperiksaan akhir semester. Seramai 20 orang pelajar adalah dari KTMP, Kuala Lumpur dan 25 orang pelajar lagi adalah dari KSKB, Kuching, Sarawak. Walau bagaimanapun, di dalam kajian ini sampel yang diperlukan bagi mewakili pelajar-pelajar tersebut menurut Krejcie dan Morgan (1970) adalah seramai 40 orang.

Menurut Johnnie (2012), pensampelan berstrata adalah prosedur pensampelan kebarangkalian di mana populasi sasaran mula-mula dipisahkan ke dalam segmen homogen yang sama, strata, dan kemudiannya sampel rawak mudah dipilih dari setiap segmen (stratum). Sehubungan itu, dengan menggunakan teknik pensampelan rawak berstrata, pemilihan sampel adalah seperti yang ditunjukkan dalam Jadual 1. Berdasarkan jadual tersebut, sampel dipisahkan kepada dua kolej yang homogen. Seterusnya, sampel bilangan pelajar dari setiap kolej diperoleh dengan menggunakan rumus 1 seperti berikut;

$$
n_{\text {kolej }}=\text { Populasi kolej / Jumlah populasi kajian X bilangan sampel yang diperlukan }
$$

Hasil pengiraan dengan menggunakan rumus 1 mendapati bahawa KTMP, Kuala Lumpur dan KSKB, Kuching, Sarawak masing-masing memerlukan 18 dan 22 orang sampel pelajar. Setelah bilangan sampel pelajar dari setiap kolej ditentukan, rumus 2 pula digunakan bagai menentukan bilangan sampel pelajar lelaki dan pelajar perempuan dari setiap kolej.

$$
\begin{gathered}
n_{\mathrm{L}}=\text { Populasi lelaki / Jumlah populasi kolej X bilangan sampel kolej } \\
n_{\mathrm{P}}=\text { Populasi perempuan / Jumlah populasi kolej X bilangan sampel kolej }
\end{gathered}
$$

Melalui pengiraan berdasarkan rumus 2 dan rumus 3, bilangan sampel pelajar lelaki dan perempuan bagi KTMP, Kuala Lumpur adalah masing-masing 15 dan tiga orang pelajar. Manakala bagi KSKB, Kuching, Sarawak pula, sampel pelajar lelaki dan perempuan adalah masing-masing sembilan dan 13 orang pelajar. Pensampelan sebegini dapat menjamin keadilan dari aspek bilangan taburan pelajar mengikut kolej dan jantina. Setelah itu, sampel-sampel pelajar dipilih secara rawak dengan bantuan perisian SPSS berdasarkan kolej dan jantina pelajar yang telah dikenal pasti. 
Jadual 1 Pensampelan kajian

\begin{tabular}{|c|c|c|c|c|c|c|c|c|}
\hline ILKKM & $N_{\mathrm{L}}$ & $N_{\mathrm{P}}$ & $N_{\text {kolej }}$ & & $n_{\text {kolej }}$ & $\bar{z}$ & $n_{\mathrm{L}}$ & $n_{\mathrm{P}}$ \\
\hline KTMP, KL & 17 & 3 & 20 & $\frac{\bar{d}}{0}$ & $\begin{array}{l}20 / 45 \times 40= \\
17.7 \approx 18\end{array}$ & 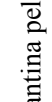 & $\begin{array}{l}17 / 20 \times 18=5.3 \\
\quad \approx 15\end{array}$ & $\begin{array}{c}3 / 20 \times 18=2.7 \\
\approx 3\end{array}$ \\
\hline $\begin{array}{l}\text { KSKB, } \\
\text { Kuching }\end{array}$ & 10 & 15 & 25 & 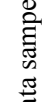 & $\begin{array}{l}25 / 45 \times 40= \\
22.2 \approx 22\end{array}$ & 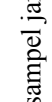 & $\begin{array}{c}10 / 25 \times 22=8.8 \\
\approx 9\end{array}$ & $\begin{array}{l}15 / 25 \times 22= \\
13.2 \approx 13\end{array}$ \\
\hline Jumlah & 27 & 18 & 45 & is & 40 & $\stackrel{\vec{E}}{\stackrel{E}{*}}$ & 24 & 16 \\
\hline
\end{tabular}

$N=$ Populasi; $n=$ Sampel; L $=$ Lelaki; $\mathrm{P}=$ Perempuan

Bagi tujuan analisis data keputusan subjek-subjek di peringkat SPM, pelajar diberi penggredan kajian pada skala 0 hingga 9 , berdasarkan kepada keputusan SPM yang mereka peroleh seperti di Jadual 2. Jika pelajar tidak menduduki peperiksaan atau tidak mengambil subjek tersebut dalam peperiksaan SPM, maka gred kajian yang akan diberikan adalah ' 0 '.

Data-data yang diperoleh adalah dianalisis secara deskriptif dan inferens. Melalui ujian normaliti, soalan kajian yang mempunyai pemboleh ubah dengan taburan data yang normal diuji dengan ujian parametrik.

Jadual 2 Perbandingan gred SPM sebelum dan mulai tahun 2009 serta penggredan kajian

\begin{tabular}{|c|c|c|c|c|}
\hline \multicolumn{2}{|c|}{ Gred SPM sebelum 2009} & \multicolumn{2}{|c|}{ Gred SPM baru mulai 2009} & \multirow{2}{*}{ Penggredan Kajian } \\
\hline Gred & Interpretasi & Gred & Interpretasi & \\
\hline- & - & $\mathrm{A}+^{+}$ & Cemerlang Tertinggi & \multirow[b]{2}{*}{9} \\
\hline $1 \mathrm{~A}$ & \multirow{2}{*}{ Cemerlang } & $\mathrm{A}$ & Cemerlang Tinggi & \\
\hline $2 \mathrm{~A}$ & & A- & Cemerlang & 8 \\
\hline $3 \mathrm{~B}$ & \multirow{4}{*}{ Kepujian } & $\mathrm{B}+$ & Kepujian Tertinggi & 7 \\
\hline $4 \mathrm{~B}$ & & $\mathrm{~B}$ & Kepujian Tinggi & 6 \\
\hline $5 \mathrm{C}$ & & $\mathrm{C}+$ & Kepujian Atas & 5 \\
\hline $6 \mathrm{C}$ & & $\mathrm{C}$ & Kepujian & 4 \\
\hline 7D & \multirow{2}{*}{ Lulus } & $\mathrm{D}$ & Lulus atas & 3 \\
\hline $8 \mathrm{E}$ & & E & Lulus & 2 \\
\hline $9 \mathrm{G}$ & Gagal & $\mathrm{G}$ & Gagal & 1 \\
\hline Tidak & duki / tidak n & & & 0 \\
\hline
\end{tabular}

\subsection{KEPUTUSAN DAN PERBINCANGAN}

Burdenski (2000) mencadangkan bahawa ujian Kolmogorov-Smirnov adalah sesuai untuk menguji normaliti bagi taburan data yang melebihi 25 data, manakala ujian Shapiro-Wilk pula digunakan untuk menguji normaliti taburan set data yang kurang daripada 25 data. Menurut Coakes dan Steed (2007), keputusan ujian Kolmogorov-Smirnov dan ujian Shapiro-Wilk dengan nilai signifikasi lebih daripada $0.05(p>0,05)$ bermaksud taburan data adalah normal. Manakala nilai signifikasi yang kurang daripada $0.05(p<0,05)$ bermaksud bahawa taburan data adalah tidak normal. Daripada analisis ke atas data markah subjek Biologi Manusia, keputusan ujian Kolmogorov-Smirnov dengan $p=0.200(p>0.05 ; n=40)$ menunjukkan bahawa taburan data adalah normal. Jadi, analisis parametrik telah dijalankan bagi menguji soalan-soalan kajian.

Daripada analisis deskriptif jantina sampel kajian, didapati 24 orang responden $(60.0 \%)$ adalah pelajar lelaki dan 16 orang responden $(40.0 \%)$ adalah pelajar perempuan. Data tersebut telah menunjukkan bahawa pelajar lelaki adalah lebih ramai daripada pelajar perempuan. Tidak seperti kebanyakan institusi pengajian tinggi yang lain di Malaysia, pelajar lelaki adalah merupakan golongan majoriti kepada pelajar yang diterima masuk bagi melanjutkan pengajian mereka ke program DTMP di ILKKM bagi sesi Julai-Disember 2012. Data kajian ini selari dengan data daripada Kementerian Pengajian Tinggi Malaysia (2010) yang menunjukkan bilangan pelajar lelaki di IPTA adalah melebihi pelajar perempuan pada sekitar tahun 1970 hingga 1999. Walau bagaimanapun, dapatan kajian ini adalah tidak selari dengan data daripada Kementerian Pengajian Tinggi Malaysia (2010) yang menunjukkan bahawa bermula pada awal tahun 2000, bilangan pelajar perempuan di IPTA adalah melebihi daripada bilangan pelajar lelaki. Senario bilangan pelajar perempuan melebihi daripada bilangan pelajar lelaki di IPTA secara tidak langsung menggambarkan bahawa pencapaian akademik pelajar perempuan adalah lebih baik daripada pelajar lelaki.

Di kalangan keseluruhan responden kajian ini, seramai 31 orang responden (77.5\%) adalah berasal dari aliran sains dan 9 orang (22.5\%) berasal dari aliran bukan-sains semasa di peringkat SPM. Ini juga menunjukkan bahawa majoriti pelajar yang mengikuti program DTMP adalah dari kalangan pelajar aliran sains yang pernah mempelajari subjek Biologi dan Kimia semasa di peringkat sekolah menengah.

\section{Keputusan Persoalan Kajian 1}

Hasil analisis deskriptif terhadap pencapaian akademik berdasarkan aliran akademik pelajar semasa di peringkat SPM adalah seperti di Jadual 3. Keputusan tersebut menunjukkan bahawa responden dari aliran sains memperoleh markah subjek Biologi Manusia yang lebih baik ( $\min =61.69$; sisihan piawai $=10.55 ; n=31$ ) berbanding dengan responden dari aliran bukan-sains $(\min =47.67$; sisihan piawai=8.39; $n=9)$. 
Jadual 3 Markah subjek Biologi Manusia mengikut aliran

\begin{tabular}{lccc}
\hline Aliran Semasa Peringkat SPM & $\mathrm{n}$ & Min & Sisihan Piawai \\
\hline Sains & 31 & 61.69 & 10.55 \\
Bukan-Sains & 9 & 47.67 & 8.39 \\
\hline
\end{tabular}

Keputusan analisis dengan Independent-Samples T Test seterusnya mengesahkan bahawa markah subjek Biologi Manusia pelajar yang berasal dari aliran sains adalah secara signifikannya lebih baik $(p<0.05 ; t=-3.653 ; d f=38)$ berbanding dengan pelajar yang berasal dari aliran bukan-sains.

Hal ini berkemungkinan berlaku berpunca daripada pengetahuan yang pelajar aliran sains perolehi hasil dari pembelajaran subjek Biologi dan Kimia di peringkat sekolah menengah dan seterusnya membantu mereka dalam pembelajaran subjek Biologi Manusia semasa mengikuti pengajian DTMP.

\section{Keputusan Persoalan Kajian 2}

Berdasarkan analisis dengan Independent-Samples T Test dan hasil analisis deskriptif terhadap keputusan Biologi Manusia responden berdasarkan jantina seperti di Jadual 4, kajian ini dapat mengesahkan bahawa pencapaian pelajar perempuan (min=63.03; sisihan piawai=12.66; $n=16)$ adalah lebih baik secara signifikan berbanding pelajar lelaki $(\min =55.53$; sisihan piawai=10.07; $n=24)$ dalam keputusan subjek Biologi Manusia $(p<0.05 ; t=-2.082 ; d f=38)$.

Jadual 4 Markah subjek Biologi Manusia mengikut jantina

\begin{tabular}{lccc}
\hline Jantina & $n$ & Min & Sisihan Piawai \\
\hline Lelaki & 24 & 55.53 & 10.07 \\
Perempuan & 16 & 63.03 & 12.66 \\
\hline
\end{tabular}

Walaupun dapatan ini tidak selari dengan kajian Patrick (2012) yang mendapati bahawa tiada perbezaan yang signifikan dalam pencapaian pelajar lelaki dan perempuan bagi subjek berteraskan Biologi, namun ia selari dengan kajian lain yang telah dijalankan oleh Zalizan et al. (2005). Zalizan et al. juga mendapati bahawa pelajar perempuan adalah lebih baik berbanding pelajar lelaki khususnya dalam tugasan yang memerlukan penghafalan fakta dan peraturan yang jelas seperti Biologi Manusia. Walaupun subjek Pengajian Am tidak mengandungi banyak elemen sains seperti subjek Biologi Manusia, hasil kajian yang dijalankan oleh Poh dan Melissa Ng (2008) juga telah mendapati bahawa pencapaian akademik pelajar perempuan di dalam subjek Pengajian Am adalah lebih baik secara signifikan berbanding pelajar lelaki. Seperti juga hasil kajian yang telah dijalankan oleh Poh dan Melissa Ng (2008), maklumat daripada hasil kajian Kementerian Pendidikan Malaysia (2000) mendapati keputusan Ujian Penilaian Sekolah Rendah (UPSR), Penilaian Menengah Rendah (PMR), dan Sijil Peperiksaan Malaysia (SPM) bagi tahun 1996 hingga 2000 juga menunjukkan bahawa pelajar perempuan telah memperoleh prestasi yang lebih baik berbanding pelajar lelaki dalam hampir semua mata pelajaran.

Dalam keadaan yang lain, terdapat juga IPTA di Malaysia seperti Universiti Teknologi Malaysia (UTM) yang didominasikan oleh pelajar lelaki kerana berteraskan bidang teknikal (psikomotor) yang sememangnya dominan di kalangan lelaki (Arham, Baharin, \& Ahmad Muhaimin, 2006). Walaupun program DTMP juga melibatkan aspek psikomotor di makmal dan lapangan, namun ia tidaklah seberat sesetengah subjek dalam bidang kejuruteraan. Malah sukatan pelajaran subjek Biologi Manusia hanya melibatkan aspek kognitif (teori) sahaja. Oleh kerana itu, bilangannya pelajar mengikut jantina adalah biasanya seimbang walaupun kumpulan responden dalam kajian ini adalah majoritinya $(60.0 \%)$ terdiri daripada pelajar lelaki.

\section{Keputusan Persoalan Kajian 3}

Hasil analisis korelasi Pearson di Jadual 5 menunjukkan nilai signifikasi korelasi di antara gred kedua-dua subjek Biologi dan Kimia di peringkat SPM terhadap markah subjek Biologi Manusia adalah signifikan dengan $p=0.00 \quad(p<0.05)$. Sehubungan itu kajian ini menyimpulkan bahawa terdapat korelasi linear positif yang signifikan di antara kedua-dua gred subjek Biologi dan Kimia di peringkat SPM terhadap markah subjek Biologi Manusia di peringkat DTMP.

Didapati juga, nilai korelasi Pearson $(r)$ antara gred subjek Biologi dan markah subjek Biologi Manusia adalah $r=0.632(39), p<0.05$. Manakala nilai korelasi Pearson antara gred subjek Kimia dan markah subjek Biologi Manusia adalah $r=0.678(39), p<0.05$. 
Jadual 5 Korelasi antara gred SPM Biologi dan Kimia terhadap markah Biologi Manusia (n=40)

\begin{tabular}{llccc}
\hline & & Markah Biologi Manusia & Gred SPM Biologi & Gred SPM Kimia \\
\hline \multirow{2}{*}{ Pearson Correlation } & Markah Biologi Manusia & 1.000 & .632 & .678 \\
& Gred SPM Biologi & .632 & 1.000 & .767 \\
& Gred SPM Kimia & .678 & .767 & 1.000 \\
\hline \multirow{2}{*}{ Sig. (1-tailed) } & Markah Biologi Manusia &. & .000 & .000 \\
& Gred SPM Biologi & .000 &. & .000 \\
\hline
\end{tabular}

Menurut Philips (2010), nilai $r$ bagi kedua-dua gred SPM Biologi dan Kimia terhadap markah subjek Biologi Manusia menunjukkan korelasi yang sangat kuat. Ini bermakna, gred subjek Biologi dan Kimia di peringkat SPM bagi seseorang pelajar didapati berperanan sangat penting di dalam pencapaian subjek Biologi Manusia program DTMP.

Hubungan korelasi yang positif tersebut telah menggambarkan bahawa semakin tinggi gred subjek Biologi dan Kimia di peringkat SPM, semakin baik juga markah subjek Biologi Manusia yang akan pelajar peroleh dalam program DTMP. Dapatan kajian ini selari dengan hasil kajian yang diperoleh oleh Neill (2011), Hecker dan Violato (2008), Noftle dan Robins (2007), dan Mathiasen (1984), yang mendapati bahawa pengetahuan terdahulu yang berkaitan subjek yang akan dipelajari di kolej mempunyai korelasi yang positif.

Seterusnya, bagi menganggarkan model regresi yang relevan, kajian ini telah menganalisis data dengan regresi berganda linear. Seperti yang ditunjukkan dalam Jadual 6, pembolehubah gred SPM Biologi dimasukkan dalam langkah pertama manakala gred SPM Kimia dimasukkan dalam langkah kedua dengan kaedah stepwise. Selepas model kedua dianggarkan, SPSS berhenti membina model baru kerana tiada pemboleh ubah yang selebihnya.

Jadual 6 Analisis regresi berganda model stepwise

\begin{tabular}{|c|c|c|c|}
\hline Model & Variables Entered & Variables Removed & Method \\
\hline 1 & Gred SPM Biologi & . & $\begin{array}{l}\text { Stepwise (Criteria: Probability- } \\
\text { of-F-to-enter }<=.050 \text {, }\end{array}$ \\
\hline 2 & Gred SPM Kimia & . & $\begin{array}{l}\text { Probability-of-F-to-remove }>= \\
.100) \text {. }\end{array}$ \\
\hline
\end{tabular}

a. Pemboleh ubah bersandar: Markah Biologi Manusia

Sebelum membuat interpretasi terhadap ujian regresi, kajian perlu menguji lineariti taburan data (assumption of linearity) dengan melihat hasil ujian ANOVA untuk mengetahui sama ada wujudnya hubungan yang linear di antara pemboleh ubah-pemboleh ubah. Ini juga akan menentukan kesesuaian model regresi berhubung dengan pemboleh ubah. Hasil ANOVA melaporkan sama ada model regresi tersebut menyebabkan atau menerangkan signifikasi ramalan statistik atau pun sebaliknya. Seperti yang ditunjukkan dalam Jadual 7, nilai $p=0.000(p<0.05)$. Jadi, boleh disimpulkan bahawa hasil kedua-dua model regresi tersebut adalah signifikan secara statistik.

Jadual 7 Ujian ANOVA a untuk data markah subjek biologi manusia dengan pemboleh ubah peramal

\begin{tabular}{llccccc}
\hline Model & & Jumlah Kuasa Dua & $d f$ & Min Kuasa Dua & $F$ & Sig. \\
\hline \multirow{2}{*}{1} & Regresi & 2107.761 & 1 & 2107.761 & 25.282 & $.000^{\mathrm{b}}$ \\
& Reja & 3168.093 & 38 & 83.371 & & \\
& Total & 5275.854 & 39 & & & \\
& Regresi & 2588.663 & 2 & 1294.332 & 17.822 & $.000^{\mathrm{c}}$ \\
& Reja & 2687.190 & 37 & 72.627 & & \\
& Total & 5275.854 & 39 & & & \\
\hline Nota: & $\begin{array}{l}\text { a. Pemboleh Ubah Bersandar: Markah Biologi Manusia } \\
\text { b. Peramal: (Pemalar), Gred SPM Biologi } \\
\text { c. Peramal: (Pemalar), Gred SPM Biologi, Gred SPM Kimia }\end{array}$ & & & &
\end{tabular}

Seperti hasil analisis regresi berganda stepwise yang ditunjukkan di Jadual 8, nilai unstandardized regression coefficient bagi SPMBio $(\mathrm{B}=1.114, \beta=0.271, p<0.05)$ dan SPMKimia $(\mathrm{B}=1.990, \beta=0.70, p<0.05)$ adalah masing-masing signifikan secara statistik. Daripada jadual tersebut, analisis turut mendapati bahawa nilai $R^{2}$ Terlaras untuk Model 2 kajian ini adalah 0.463 dengan $R^{2}=0.491$. Ini bermakna, 
model regresi berganda linear dengan pemboleh ubah bebas gred subjek Biologi meramalkan sebanyak 40.0 peratus varian pencapaian subjek Biologi Manusia dalam program DTMP.

Manakala gred subjek Kimia pula meramalkan 9.1 peratus varian pencapaian subjek Biologi Manusia dalam program DTMP. Malah, melalui analisis regresi berganda linear ini, gabungan kedua-dua gred SPM subjek Biologi dan Kimia yang baik didapati berupaya meramalkan pelajar untuk memperoleh markah subjek Biologi Manusia dengan lebih baik.

Jadual 8 Ringkasan Analisis regresi berganda stepwise bagi pemboleh ubah peramal terhadap pencapaian ujian subjek biologi manusia $(\mathrm{n}=40)$

\begin{tabular}{|c|c|c|c|c|c|c|}
\hline \multirow{2}{*}{ Pemboleh Ubah } & \multicolumn{3}{|c|}{ Model 1} & \multicolumn{3}{|c|}{ Model 2} \\
\hline & $B$ & Ralat Piawai $B$ & $\operatorname{Beta}(\beta)$ & $B$ & Ralat Piawai $B$ & $\operatorname{Beta}(\beta)$ \\
\hline Pemalar & 48.736 & 2.425 & & 45.720 & 2.549 & \\
\hline SPMBio & 2.595 & .516 & $.632 * * *$ & 1.114 & .751 & $.271 *$ \\
\hline SPMKimia & & & & 1.990 & .773 & $.470^{*}$ \\
\hline$R^{2}$ & & 0.400 & & & 0.491 & \\
\hline Perubahan $F$ & & 25.282 & & & 6.622 & \\
\hline$R^{2}$ Terlaras & & 0.384 & & & 0.463 & \\
\hline
\end{tabular}

Dalam Jadual 8 juga, keputusan analisis menunjukkan multiple linear regression coefficient yang menganggarkan beberapa parameter termasuk intercept dan tahap signifikan. Dalam Model 2, keputusan analisis mendapati intercept yang signifikan serta highly significant coefficients bagi gred SPM Biologi dan gred SPM Kimia. Rumus persamaan matematik bagi model regresi berganda linear kajian ini adalah seperti berikut; Markah MPBM $=45.720+1.114($ Biologi) $+1.990($ Kimia) .

Rumus tersebut bermaksud, bagi pertambahan setiap unit yang dicapai pada gred SPM Biologi, kita boleh menganggarkan bahawa markah subjek Biologi Manusia meningkat sebanyak 1.114, manakala bagi pertambahan setiap unit yang dicapai pada gred SPM Kimia, markah subjek Biologi Manusia akan meningkat sebanyak 1.990.

Oleh kerana data kajian mempunyai multiple independent variables dalam analisis, Beta weights dapat membandingkan kepentingan relatif setiap pemboleh ubah bebas dalam standardized terms. Dengan itu, keputusan analisis data juga telah menunjukkan bahawa gred SPM Kimia mempunyai impak yang lebih tinggi berbanding gred SPM Biologi dengan nilai Beta masing-masing adalah 0.470 dan 0.271.

Selain itu, keputusan analisis ke atas data juga telah menunjukkan nilai Tolerance $>0.1$ bagi kedua-dua gred SPM Biologi dan gred SPM Kimia. Ini menunjukkan bahawa pemboleh ubah-pemboleh ubah tidak bersandar yang dikaji dalam kajian ini adalah tidak bersandar di antara satu sama lain secara signifikan. Hal bagi memastikan agar pemboleh ubah-pemboleh ubah yang dikaji tidak bersandar adalah penting. Menurut Dormann et al. (2013), nilai multicollinearity adalah sejauh mana pemboleh ubah bebas berkaitan di antara satu sama lain. Untuk itu, nilai Tolerance harus lebih besar daripada 0.1 (atau nilai VIF $<10$ ) bagi semua pemboleh ubah. Jika nilai Tolerance adalah kurang daripada 0.1, ini akan mewujudkan syak terhadap multicollinearity, dan dengan nilai Tolerance yang kurang daripada 0.01, ini menunjukkan bukti terhadap multicollinearity. Walau bagaimanapun, seperti yang telah dijelaskan, isu multicollinearity tidak wujud dalam kajian ini.

\subsection{KESIMPULAN}

Daripada hasil analisis terhadap data dalam kajian ini, dapat dibuat kesimpulan bahawa syarat kelayakan calon untuk urusan pengambilan pelajar bagi mengikuti pengajian DTMP perlu dipertingkatkan. Dapatan ini selari dengan hasil kajian Neill (2011) dan Mathiasen (1984) yang mendapati bahawa skor ujian dan pencapaian terdahulu di sekolah menengah adalah peramal terbaik untuk kejayaan di kolej. Ini bermaksud, calon bukan sahaja perlu mempunyai latar belakang dari aliran sains semasa di peringkat sekolah menengah, tambahan kepada itu calon-calon perlu mempunyai latar belakang pencapaian gred subjek Biologi dan Kimia yang baik di peringkat SPM. Jika kelayakan kemasukan ke program DTMP ini dapat dipertingkatkan berbanding syarat yang sedia ada sekarang, maka kegagalan dalam subjek Biologi Manusia akan dapat diminimumkan dan sekali gus meningkatkan prestasi keseluruhan terhadap keputusan peperiksaan tersebut.

Berkaitan dengan dapatan kajian ini yang menunjukkan bahawa pelajar lelaki perlu diberikan lebih perhatian semasa sesi pengajaran khususnya dalam sesi pembelajaran subjek Biologi Manusia, ia adalah selari dengan kajian yang telah dijalankan oleh Lestari (2010) dan Zalizan et al. (2005) yang turut mendapati bahawa keputusan akademik pelajar perempuan adalah lebih baik. Tetapi, hasil dapatan kajian ini berkaitan pencapaian subjek Biologi Manusia adalah tidak selari dengan hasil kajian Patrick (2012) yang mendapati pencapaian pelajar lelaki lebih baik berbanding pelajar perempuan bagi subjek Kimia dan tidak terdapat perbezaan yang signifikan antara lelaki dan perempuan dalam keputusan subjek Biologi. Oleh sebab subjek Biologi Manusia mengandungi komponen subjek Biologi dan Kimia, keputusan yang tidak selari tersebut mungkin disebabkan oleh faktor sampel kajian Patrick (2012) yang menggunakan sampel seramai 637 orang pelajar berbanding hanya 40 orang pelajar dalam kajian ini. Walau bagaimanapun, berdasarkan hasil kajian ini, perhatian yang lebih terhadap pelajar lelaki dalam pembelajaran subjek Biologi Manusia tetap perlu dilakukan sebagai salah satu usaha meningkatkan pencapaian mereka.

Hasil kajian ini adalah relevan dengan situasi pengajian di ILKKM buat masa ini yang perlu ditingkatkan tarafnya seiring dengan kenaikan elaun bulanan pelajar bermula sesi Januari 2013. Malah, apabila pelajar telah tamat pengajian kelak, mereka akan menjadi pasukan hadapan (front liner) dalam mengenal pasti penyakit di makmal-makmal patologi hospital dan klinik di seluruh negara. Maka, 
adalah penting jika kita tidak mahu berkompromi dalam rawatan terhadap pesakit, maka kita tidak sepatutnya juga berkompromi dalam hal yang melibatkan pengambilan pelajar-pelajar yang bakal menjadi aset dalam sistem kesihatan negara.

Walaupun terdapat kajian-kajian dari luar negara yang kurang selari dengan kajian ini, ia tidak boleh digeneralisasikan terus kepada konteks tempatan kerana sistem pendidikan, komposisi etnik dan suasana pembelajaran di Malaysia khususnya program DTMP di KTMP, Kuala Lumpur dan KSKB, Kuching, Sarawak adalah berbeza dari negara-negara lain. Semoga kajian ini dapat menyumbang dari segi penyelidikan dan memberikan satu perspektif baru dalam menilai kemasukan pelajar ke program DTMP. Oleh sebab kajian ini tidak mengkaji faktor-faktor lain yang mungkin juga dapat meramal pencapaian pelajar khususnya bagi subjek Biologi Manusia, diharapkan agar kajian ini tidak berhenti di sini sahaja. Kajian ini boleh diperluaskan lagi kepada menyelidik faktor-faktor lain serta diaplikasikan terhadap program-program pengajian lain yang berkaitan secara keseluruhannya.

\section{Rujukan}

Arham, A., Baharin, M., \& Ahmad Muhaimin, M. (2006). Faktor-Faktor Yang Menyumbang Kepada Kecemerlangan Akademik Pelajar Di Universiti Teknologi Malaysia. Diperolehi pada Oktober 2011, dari laman sesawang http://eprints.utm.my.

Bahagian Pengurusan Latihan. (2010). Laman Web Rasmi Bahagian Pengurusan Latihan, KKM. Diperolehi pada 2 Ogos 2011, dari laman sesawang Kementerian Kesihatan Malaysia: http://latihan.moh.gov.my.

Bahagian Pengurusan Latihan. (2012). Struktur Penilaian Program Diploma Teknologi Makmal Perubatan KKM. Putrajaya: Bahagian Pengurusan Latihan, KKM.

Bahagian Pengurusan Latihan. (2014). Kursus Pra Perkhidmatan Anggota Sains Kesihatan Bersekutu (Separa Perubatan) KKM. Diperolehi pada 1 Mac 2014, dari laman sesawang Bahagian Pengurusan Latihan: http://latihan.moh.gov.my.

Breier, M. (2010). From 'Financial Considerations' To 'Poverty': Towards A Reconceptualisation Of The Role Of Finances In Higher Education Student Drop Out. High Educ, 60, 657-670.

Burdenski, T. (2000). Evaluating Univariate, Bivariate, And Multivariate Normality Using Graphical And Statistical Procedures. Multiple Linear Regression Viewpoint, 26(2), 15-28.

Campbell, N. A., Mitchell, L. G., \& Reece, J. B. (1994). Biology Concept And Connections. Ontario: The Benjamin \& Cummings Publishing.

Coakes, S., \& Steed, L. (2007). SPSS Version 14.0 For Windows. Australia: John Wiley \& Sons Australia.

Dormann, C. F., Elith, J., Bacher, S., Buchmann, C., Carl, G., Carré, G., et al. (2013). Collinearity: A Review Of Methods To Deal With It And A Simulation Study Evaluating Their Performance. Ecography, 36, 27-46.

Hecker, K., \& Violato, C. (2008). How Much Do Differences In Medical Schools Influence Student Performance? A Longitudinal Study Employing Hierarchical Linear Modeling. Teaching and Learning in Medicine: An International Journal, 20(2), 104-113.

Holstein, A.-F., Schulze, W., \& Davidoff, M. (2003). Understanding Spermatogenesis Is A Prerequisite For Treatment. Reproductive Biology and Endocrinology, 107(1), 1-16

Johnnie, D. (2012). Sampling Essentials: Practical Guidelines for Making Sampling Choices. Thousand Oaks, California: Sage Publication.

Jonid, M., \& Ahmad Razali, H. (2010). Membangunkan Modul Perisian Alat Bantu Mengajar (Abm) Berasaskan Komputer Bertajuk 'Variation' Bagi Mata Pelajaran Biologi Tingkatan Lima. Johor Bahru: UTM.

Kementerian Kesihatan Malaysia. (2007). Diploma Teknologi Makmal Perubatan. Kuala Lumpur: Training Division.

Kementerian Kesihatan Malaysia. (2009). Teacher's Guide Year 1 Semester I - Diploma in Nursing. Kuala Lumpur: Kementerian Kesihatan Malaysia.

Kementerian Pendidikan Malaysia. (1998). Huraian sukatan pelajaran Biologi. KBSM (Edisi Sekolah Bestari). Kuala Lumpur: Pusat Perkembangan Kurikulum.

Kementerian Pendidikan Malaysia. (2000). Perangkaan Pendidikan Malaysia. Kuala Lumpur: Kementerian Pendidikan Malaysia.

Kementerian Pengajian Tinggi Malaysia. (2010). Laporan Kajian Pengesanan Graduan Susulan SKPG II 2008 / 2009. Putrajaya: Kementerian Pengajian Tinggi Malaysia.

Khurana, I., Khurana, A., Hwee Ming, C., Selvaratnam, L., Wan Ling, L., \& Soo Nyet, T. (2010). Fundamantals Of Anatomy And Physiology For Nursing And Allied Health. Shah Alam: Oxford.

King, B. M., \& Minium, E. W. (2008). Statistical Reasoning in the Behavioral Sciences (5th ed.). New Jersey, USA: John Wiley \& Sons, Inc.

Krejcie, R. V., \& Morgan, D. W. (1970). Determining sample sizes for research activities. Educational and Psychological Measurement, 30, 607-610.

Lestari, E. (2010). Gender as a predictor for academic achievement. Health Science Journal of Indonesia, 1(1), 43-50.

Manoharan, P. K. (2009). Research Methodology. New Delhi: APH Publishing Corporation.

Mathiasen, R. E. (1984). Predicting College Academic Achievement: A Research Review. College Student Journal, 18(4), 380-386

Neill, M. A. (2011). Graduate-entry Nursing Students' Experiences Of An Accelerated Nursing Degree - A Literature Review. Nurse Education in Practice, 11, 81-85.

Noftle, E. E., \& Robins, R. W. (2007). Personality Predictors Of Academic Outcomes-Big Five Correlates of GPA and SAT Scores. Journal of Personality and Social Psychology, 93(1), 116-130.

Patrick, A. O. (2012). Unequal Achievement of Science Undergraduates: Does Sex Influence the Differences? US-China Education Review, 578-594.

Phillips, J. A. (2010). Quantitative Research Methodology. Kuala Lumpur: Open University Malaysia.

Poh, B. T., \& Ng, M. L. (2008). Kesan Faktor Jantina, Etnik dan Gaya Kognitif Ke Atas Pencapaian Pengajian Am. Jurnal Pendidik dan Pendidikan, 23, 123-140.

Pusat Perkembangan Kurikulum. (2000). Sukatan Pelajaran Kurikulum Bersepadu Sekolah Menengah: Kimia. Kuala Lumpur: Kementerian Pendidikan Malaysia.

Scanlon, V. C., \& Sanders, T. (2011). Essentials of Anatomy and Physiology (Sixth ed.). Philadelphia: F.A. Davis Company.

Tidewater Community College. (2013). Anatomy and Physiology Prerequisite Mandatory Beginning Fall 2013. US Fed News Service, Including US State News. Norfolk, Washington, D.C., USA: HT Media Ltd.

Warner, R. M. (2008). Applied Statistics: From Bivariate Through Multivariate. USA: Sage Publications, Inc.

Wright, B., \& Linacre, J. M. (1994). Reasonable Mean-Square Fit Values. Rasch Measurement Transactions, 8, 370

Zalizan, M. J., Saemah, R., Roselan, B., \& Jamil, A. (2005). Prestasi Akademik Mengikut Gender. Jurnal Pendidikan Malaysia, 30, $93-111$. 